\title{
BIODISTRIBUTION STUDIES OF BEE VENOM AND SPIDER TOXIN USING RADIOTRACERS
}

\author{
YONAMINE C. M. (1), COSTA H.(1), SILVA J. A. A. (1), MURAMOTO E. (1), \\ ROGERO J. R. (1), TRONCONE L. R. P. (2), CAMILLO M. A. P. (1)
}

(1) Centro de Biologia Molecular, Instituto de Pesquisas Energéticas e Nucleares, CNEN, São Paulo, Brazil; (2) Laboratório de Farmacologia, Instituto Butantan, São Paulo, Brazil.

\begin{abstract}
The use of radiotracers allows the understanding of the bioavailability process, biodistribution, and kinetics of any molecule labelled with an isotope, which does not alter the molecule's biological properties. In this work, technetium-99m and iodine-125 were chosen as radiotracers for biodistribution studies in mice using bee (Apis mellifera) venom and a toxin (PnTX2-6) from the Brazilian "armed" spider (Phoneutria nigriventer) venom. Incorporated radioactivity was measured in the blood, brain, heart, lung, liver, kidney, adrenal gland, spleen, stomach, testicle, intestine, muscle, and thyroid gland. Results provided the blood kinetic parameter, and different organs distribution rates.
\end{abstract}

KEY WORDS: Phoneutria nigriventer, Apis mellifera, toxin, venom, radiotracer, biodistribution.

CORREPONDENCE TO: M.A.P. Camillo - Centro de Biologia Molecular, Instituto de Pesquisas Energéticas e Nucleares, Av. Lineu Prestes, 2242, Cidade Universitária, 05508-900, São Paulo, Brasil. Email: mcamillo@ipen.br 


\section{INTRODUCTION}

The advantages of using radiotracers are widely acknowledged in medicine, both for diagnosis and therapy. Though radiotracers allow an important approach to understand the bioavailability process, biodistribution, and kinetics of any toxin, their use in animal venom researches has been very scanty.

Animal venoms and mainly the isolated toxins have been important tools in biochemical, physiological, and pathological studies, as well as in the development of new drugs. Their biological activities are selective, specific, and very often present synergetic action. Animal venoms share basic features, such as being complex mixture of proteins and peptides with great structural diversity.

In this work, there are two assays with different radiotracers: technetium-99m and iodine-125. They were chosen as radiotracers for biodistribution studies of a complex mixture (bee venom) and an isolated peptide (PnTX2-6 toxin) in mice. These toxins have very different chemical characteristics, such as presenting low molecular weight components with high toxicity. They are also of clinical interest due to the high frequency of severe accidents involving human beings $(1,3)$.

The aim of this study is to show the feasibility of assays with radiotracers and learn more about transport mechanism, compartments involved, and residence time in sites of action for the toxin and venom chosen.

\section{MATERIAL AND METHODS}

Apis mellifera (Hymenoptera, Apidae) venom in high degree of purity was supplied by the Center for the Studies of Social Insects (CEIS - UNESP, Rio Claro, São Paulo State, Brazil), and Phoneutria nigriventer venom was obtained from Butantan Institute (São Paulo, Brazil). Both were collected by the electric shock method, then frozen and lyophilized.

$\mathrm{Na}^{125} \mathrm{I}$ was purchased from MDS Nordion, and the ${ }^{99} \mathrm{Mo} /{ }^{99 \mathrm{~m}} \mathrm{Tc}$ generator from the Radiopharmaceutical Center, IPEN (São Paulo, Brazil). The toxin was labelled with iodine-125, and Apis mellifera venom with technetium-99m

\section{PnTX2-6 toxin preparation}

Phoneutria nigriventer venom was dissolved in cold ammonium formiate buffer, 100 $\mathrm{mM}, \mathrm{pH}$ 6.0, and centrifuged at $10000 \mathrm{~g}$ for 5 minutes. The soluble phase was fractionated in two steps: in Sephadex G-50 gel with the same dissolution buffer, and 
in reverse phase HPLC (column $\mu$ RPC C2/C18 - Pharmacia, using extended linear gradients of acetonitrile in $0.1 \%(\mathrm{v} / \mathrm{v})$ aqueous trifluoroacetic acid).

\section{Apis mellifera venom labelling with 99m-Tecnetium}

Sodium pertechnetate $\left(\mathrm{Na}^{99 \mathrm{~m}} \mathrm{TcO}_{4}\right)$ in saline solution was obtained from the ${ }^{99} \mathrm{Mo} /{ }^{99 \mathrm{~m}} \mathrm{Tc}$ generator. The labelling reaction was performed by incubating for 30 minutes, at room temperature, a solution with ${ }^{99 \mathrm{~m}} \mathrm{Tc}(55.5 \mathrm{MBq}$, radiochemical purity $\geq 98 \%$ ) and bee venom solution: $20 \mu \mathrm{L}$ of ${ }^{99 \mathrm{~m}} \mathrm{Tc} \mathrm{MDP} . \mathrm{SnCl}_{2} . \mathrm{H}_{2} \mathrm{O}(5.1 \mathrm{mg} / \mathrm{mL}, \mathrm{pH} 6.4)$ and $125 \mu \mathrm{L}$ of venom solution $(2 \mathrm{mg} / \mathrm{mL}$ in saline). After the reaction, volume was increased with saline solution in order to carry out the biodistribution studies in animal models.

\section{PnTX2-6 toxin labelling with $\mathrm{Na}^{125}$ I}

For the isolated peptide labelling, a method that uses chloramine $T$ under mild conditions and low temperature was chosen (4). The reaction mixture was fractionated in gel filtration to separate the radioiodinated toxin from free iodine-125 and other contaminants.

\section{Tracers control}

In order to evaluate the ${ }^{99 \mathrm{~m}} \mathrm{Tc}$-labelled compounds radiochemical purity, the analyses were conducted in HPLC, with TOSO HAAS, TSK-G2000 column, using linear gradient of water-acetonitrile-phosphoric acid 85\% (500:1:1). For ${ }^{125}$ I-toxin, an additional control with measurement of iodine-125 in all the injected mice thyroid gland was carried out.

\section{Kinetic assay and bioavailability}

For the kinetic assay and bioavailability, adult Balb/C male mice were used. The animals received food and water ad libitum, and were kept in a room with natural light and controlled temperature $\left(20^{\circ} \mathrm{C}\right) .{ }^{99 \mathrm{~m}} \mathrm{TC}$-venom was intraperitoneally injected, and ${ }^{125}$ I-toxin, intravenously injected. The animals were sacrificed 5, 15, 30 minutes, 1, 2, 4,7 , and 24 hours after the injections.

Incorporated radioactivity was measured with a gamma counter (Cobra II, Packard Instrument Ltd.) in the blood, spleen, brain, heart, stomach, liver, intestine, muscle, lung, kidney, testicles, and thyroid gland. Corrections related to radioactive decay were made just for technetium-99m ( $T_{1 / 2} 6.01$ hours), not been required for iodine125 ( $T_{1 / 2} 59.6$ days). 
In the biodistribution analysis, radiotracer concentration in each organ was expressed as the percentage of injected tracers per mass unit of tissue $(\% \mathrm{D} / \mathrm{g})$. Kinetic behaviour was estimated by using a graph of the mean \%D/g versus time (logxlog).

Blood analysis was performed by plotting the radioactivity measured in the collected samples versus time (cpm/50 $\mu \mathrm{L}$ for ${ }^{125} \mathrm{I}$-PnTX2-6 toxin and $\mathrm{cpm} / \mathrm{mL}$ for ${ }^{99 \mathrm{~m}} \mathrm{Tc}$-bee venom). Data were fitted to exponential decay models (one or two compartments). This adjustment uses the conventional compartments model and allows the access to information about distribution, metabolism, and elimination.

Statistical analysis and calculations were carried out with Microsoft Excel and GraphPad Prism softwares.

\section{RESULTS}

Technetium-99m incorporation and radioiodination procedure yields were adequate. The chromatographic analysis demonstrated that unbound radioisotope decreased to less than $3 \%$ in both cases after purification (removal of unreacted radioisotope). This percentage was insignificant and is reflected by the low initial thyroid gland uptake in mice injected with radioiodinated PnTX2-6 toxin. This gland actively uptakes free iodine, being a good indicator of this preparation radiochemical purity, mainly at the initial time. The thyroid gland graph shows that free iodine-125 uptake was only observed after 30 minutes, suggesting that it would be the degradation product of toxin metabolism.

In the Tables and Figures, the mean value obtained shows a kinetic profile for each organ and the blood.

Figure 1 shows the kinetics for ${ }^{125}$ I-toxin PnTX2-6 in different organs; data were summarized in Table 1. Analysis of the data obtained from the blood and the kinetic parameter calculated suggest a two-compartmental model - a central and a peripheral compartment.

There are many organs in the peripheral compartment that interact with the toxin; so it is not possible to indicate only one target. No significant difference was found in the final phase of the curves for organs with similar biologic half-life. 
Figure 2 and Table 2 show the ${ }^{99 m}$ Tc-bee venom results. The experimental data could not be fitted to the one or two-compartmental models and only a plotted curve was proposed.
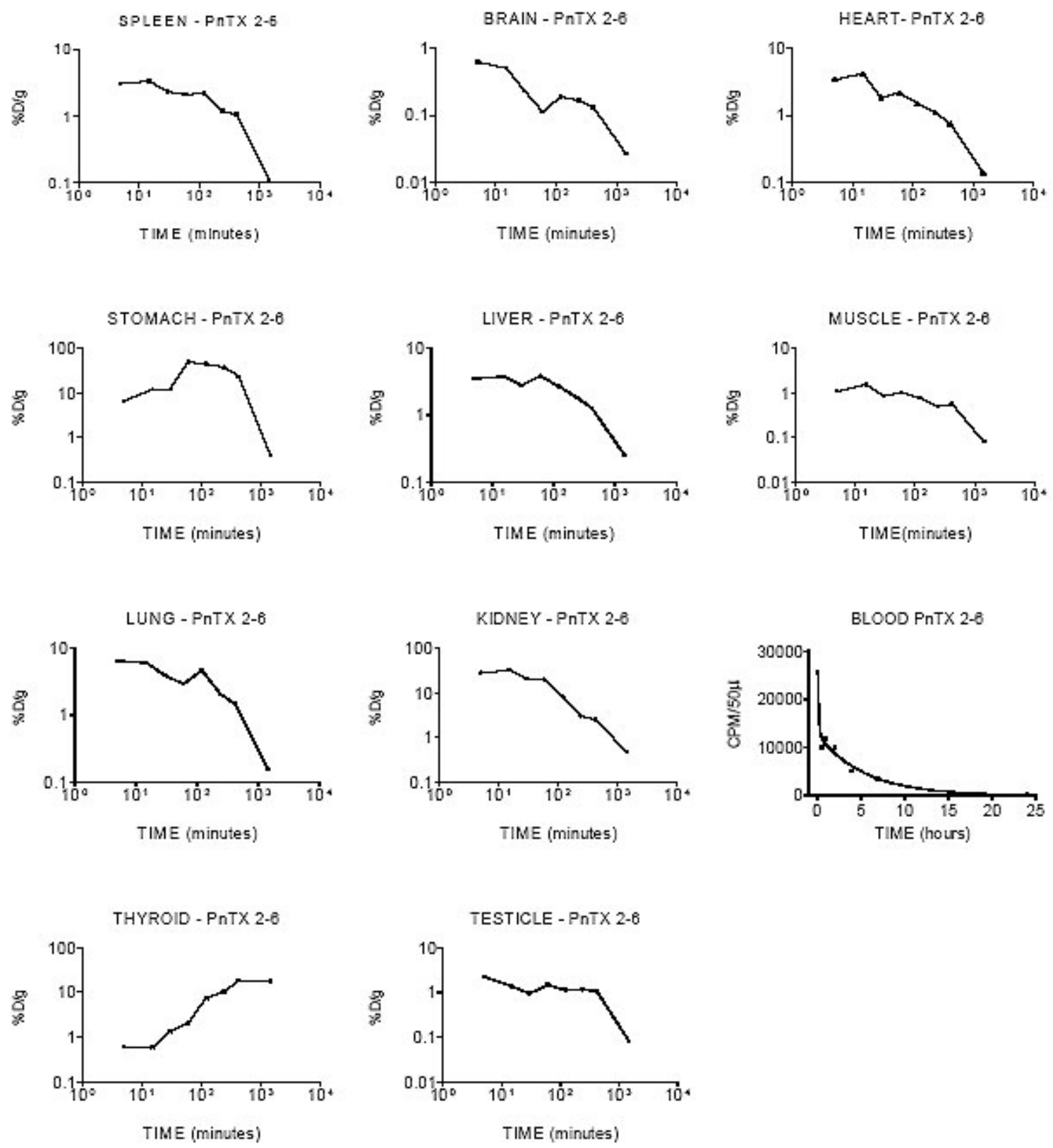

Figure 1. ${ }^{125}$ I-PnTX2-6 toxin kinetic behaviour in different organs over 24 hours after intravenous administration. Data were expressed as the percentage of total dose (\%D) injected per tissue weight (g) or $50 \mu \mathrm{L}$ of blood sample versus time.

Blood sample data were adjusted by two phases: exponential decay or open two-compartmental model $\left(C_{t}=A \cdot e^{-\alpha t}+B \cdot e^{-\beta t}\right)$. B is the intercept of the back-extrapolated monoexponential elimination slope $\beta$ with the ordinate; $A$ is the intercept of the distribution slope $\alpha$ with the ordinate $(27,890$ and $12,780 \mathrm{cpm} / 50 \mu \mathrm{L}) ; \alpha$ and $\beta$ are the absorption and elimination hybrid constants, respectively (9.242 and 0.1873). 

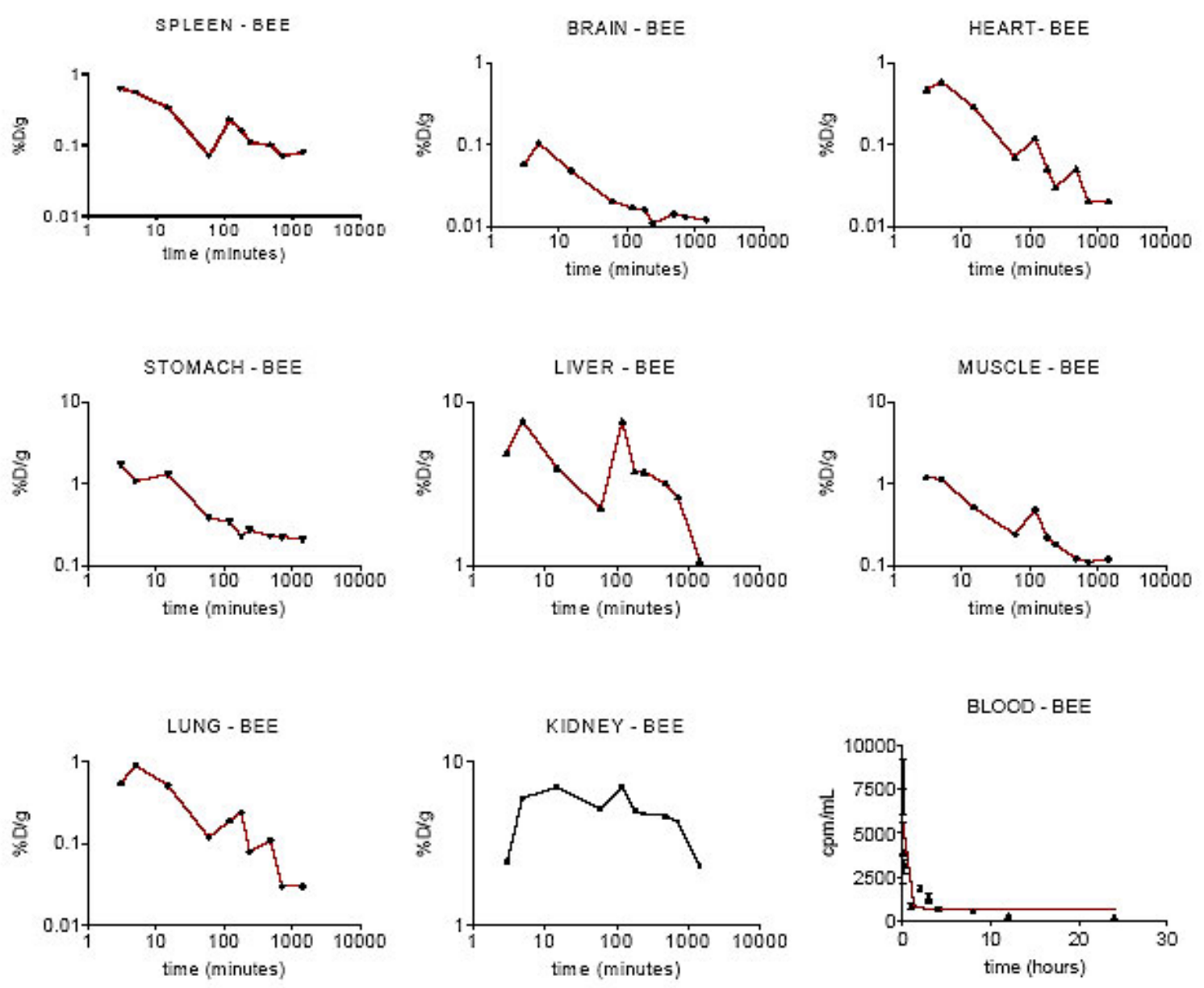

Figure 2. ${ }^{99 \mathrm{~m}} \mathrm{Tc}$-Apis mellifera venom kinetic behaviour in different organs over 24 hours after intraperitoneal administration. Data were expressed as the percentage of total dose $(\% \mathrm{D})$ injected per tissue weight $(\mathrm{g})$ or $1 \mathrm{~mL}$ of blood sample versus time. Blood curves were plotted with experimental points. 
Table 1. ${ }^{125}$ I-PnTX2-6 toxin distribution in different organs of mice sacrificed over 24 hours after intraperitoneal administration. Data were expressed as the percentage of total dose injected per tissue weight (\% $D / g \pm$ S.D).

\begin{tabular}{|c|c|c|c|c|c|c|c|c|c|c|c|}
\hline $\begin{array}{l}\text { Toxin } \\
\text { Time } \\
\text { (hours) }\end{array}$ & Brain & Heart & Lung & Liver & Kidney & Spleen & Stomach & Testicles & Intestine & Muscle & Thyroid \\
\hline 0.083 & $\begin{array}{c}0.623 \pm \\
0.396\end{array}$ & $\begin{array}{l}3.417 \pm \\
0.227\end{array}$ & $\begin{array}{c}6.383 \pm \\
0.396\end{array}$ & $\begin{array}{c}3.493 \pm \\
1.228\end{array}$ & $\begin{array}{c}27.760 \pm \\
2.015\end{array}$ & $\begin{array}{c}3.080 \pm \\
0.246\end{array}$ & $\begin{array}{l}6.540 \pm \\
2.082\end{array}$ & $\begin{array}{l}2.300 \pm \\
2.113\end{array}$ & $\begin{array}{l}0.967 \pm \\
0.050\end{array}$ & $\begin{array}{l}1.073 \pm- \\
0.140\end{array}$ & $\begin{array}{l}0.607 \pm- \\
0.662\end{array}$ \\
\hline 0.250 & $\begin{array}{c}0.507 \pm \\
0.130\end{array}$ & $\begin{array}{l}4.160 \pm \\
1.732\end{array}$ & $\begin{array}{c}6.047 \pm \\
1.562\end{array}$ & $\begin{array}{c}3.773 \pm \\
1.624\end{array}$ & $\begin{array}{c}31.803 \pm \\
6.167\end{array}$ & $\begin{array}{l}3.333 \pm \\
1.151\end{array}$ & $\begin{array}{l}12.203 \pm \\
4.648\end{array}$ & $\begin{array}{l}1.377 \pm \\
0.707\end{array}$ & $\begin{array}{l}5.627 \pm \\
6.635\end{array}$ & $\begin{array}{l}1.527 \pm \\
0.491\end{array}$ & $\begin{array}{l}0.603 \pm \\
0.413\end{array}$ \\
\hline 0.500 & $\begin{array}{c}0.230 \pm \\
0.010\end{array}$ & $\begin{array}{l}1.840 \pm \\
0.699\end{array}$ & $\begin{array}{c}3.910 \pm \\
0.286\end{array}$ & $\begin{array}{c}2.790 \pm \\
0.280\end{array}$ & $\begin{array}{c}20.603 \pm \\
1.283\end{array}$ & $\begin{array}{l}2.320 \pm \\
0.596\end{array}$ & $\begin{array}{l}12.163 \pm \\
5.058\end{array}$ & $\begin{array}{l}0.957 \pm \\
0.172\end{array}$ & $\begin{array}{l}1.170 \pm \\
0.246\end{array}$ & $\begin{array}{l}0.840 \pm \\
0.320\end{array}$ & $\begin{array}{l}1.370 \pm \\
0.720\end{array}$ \\
\hline 1 & $\begin{array}{c}0.113 \pm \\
0.068\end{array}$ & $\begin{array}{l}2.187 \pm \\
0.835\end{array}$ & $\begin{array}{c}2.890 \pm \\
0.865\end{array}$ & $\begin{array}{c}3.830 \pm \\
1.244\end{array}$ & $\begin{array}{c}19.493 \pm \\
9.862\end{array}$ & $\begin{array}{l}2.097 \pm \\
0.410\end{array}$ & $\begin{array}{l}49.413 \pm \\
9.301\end{array}$ & $\begin{array}{l}1.480 \pm \\
0.663\end{array}$ & $\begin{array}{c}1.593 \pm \\
1.135\end{array}$ & $\begin{array}{l}0.997 \pm \\
0.465\end{array}$ & $\begin{array}{l}2.087 \pm \\
0.402\end{array}$ \\
\hline 2 & $\begin{array}{c}0.190 \pm \\
0.101\end{array}$ & $\begin{array}{l}1.520 \pm \\
0.272\end{array}$ & $\begin{array}{c}4.597 \pm \\
2.215\end{array}$ & $\begin{array}{c}2.693 \pm \\
1.134\end{array}$ & $\begin{array}{c}8.153 \pm \\
2.606\end{array}$ & $\begin{array}{l}2.220 \pm \\
0.270\end{array}$ & $\begin{array}{l}44.417 \pm \\
6.130\end{array}$ & $\begin{array}{l}1.130 \pm \\
0.877\end{array}$ & $\begin{array}{l}1.660 \pm \\
0.262\end{array}$ & $\begin{array}{l}0.777 \pm \\
0.110\end{array}$ & $\begin{array}{l}7.610 \pm \\
1.273\end{array}$ \\
\hline 4 & $\begin{array}{c}0.167 \pm \\
0.137\end{array}$ & $\begin{array}{l}1.087 \pm \\
0.765\end{array}$ & $\begin{array}{c}2.063 \pm \\
0.203\end{array}$ & $\begin{array}{c}1.830 \pm \\
0.451\end{array}$ & $\begin{array}{c}3.017 \pm \\
0.523\end{array}$ & $\begin{array}{l}1.197 \pm \\
0.280\end{array}$ & $\begin{array}{c}37.537 \pm \\
7.701\end{array}$ & $\begin{array}{l}1.167 \pm \\
0.197\end{array}$ & $\begin{array}{l}1.150 \pm \\
0.205\end{array}$ & $\begin{array}{l}0.493 \pm \\
0.072\end{array}$ & $\begin{array}{l}10.537 \pm \\
0.722\end{array}$ \\
\hline 7 & $\begin{array}{c}0.130 \pm \\
0.085\end{array}$ & $\begin{array}{l}0.740 \pm \\
0.286\end{array}$ & $\begin{array}{c}1.473 \pm \\
0.832\end{array}$ & $\begin{array}{c}1.267 \pm \\
0.153\end{array}$ & $\begin{array}{c}2.483 \pm \\
0.704\end{array}$ & $\begin{array}{l}1.047 \pm \\
0.416\end{array}$ & $\begin{array}{l}23.513 \pm \\
2.570\end{array}$ & $\begin{array}{l}1.067 \pm \\
0.344\end{array}$ & $\begin{array}{l}1.357 \pm \\
0.202\end{array}$ & $\begin{array}{l}0.557 \pm \\
0.105\end{array}$ & $\begin{array}{l}18.470 \pm \\
3.684\end{array}$ \\
\hline 24 & $\begin{array}{c}0.027 \pm \\
0.015\end{array}$ & $\begin{array}{l}0.140 \pm \\
0.036\end{array}$ & $\begin{array}{c}0.157 \pm \\
0.074\end{array}$ & $\begin{array}{c}0.257 \pm \\
0.058\end{array}$ & $\begin{array}{c}0.463 \pm \\
0.175\end{array}$ & $\begin{array}{l}0.113 \pm \\
0.047\end{array}$ & $\begin{array}{l}0.397 \pm \\
0.346\end{array}$ & $\begin{array}{l}0.083 \pm \\
0.040\end{array}$ & $\begin{array}{l}0.052 \pm \\
0.068\end{array}$ & $\begin{array}{l}0.080 \pm \\
0.050\end{array}$ & $\begin{array}{l}18.387 \pm \\
3.062\end{array}$ \\
\hline
\end{tabular}


Table 2. ${ }^{99 \mathrm{~m}}$ Tc-Apis mellifera venom distribution in different organs of mice sacrificed over 24 hours after intraperitoneal administration. Data were expressed as the percentage of total dose injected per tissue weight (\% D/g \pm S.D).

\begin{tabular}{|c|c|c|c|c|c|c|c|c|c|}
\hline $\begin{array}{l}\text { Bee } \\
\text { venom } \\
\text { Time } \\
\text { (hours) }\end{array}$ & Brain & Heart & Lung & Liver & Kidney & Spleen & Stomach & Muscle & Thyroid \\
\hline 0.050 & $\begin{array}{l}0.057 \pm \\
0.010\end{array}$ & $\begin{array}{c}0.47 \pm \\
0.09\end{array}$ & $\begin{array}{c}0.55 \pm \\
0.12\end{array}$ & $\begin{array}{c}4.88 \pm \\
1.51\end{array}$ & $\begin{array}{l}2.44 \pm \\
1.71\end{array}$ & $\begin{array}{c}0.63 \pm \\
0.21\end{array}$ & $\begin{array}{c}1.72 \\
\pm 0.11\end{array}$ & $\begin{array}{c}1.19 \\
\pm 0.66\end{array}$ & $\begin{array}{r}0.18 \\
\pm 0.01\end{array}$ \\
\hline 0.083 & $\begin{array}{l}0.105 \pm \\
0.030\end{array}$ & $\begin{array}{c}0.59 \pm \\
0.18\end{array}$ & $\begin{array}{c}0.92 \pm \\
0.24\end{array}$ & $\begin{array}{c}7.67 \pm \\
0.68\end{array}$ & $\begin{array}{l}6.04 \pm \\
0.85\end{array}$ & $\begin{array}{c}0.56 \pm \\
0.27\end{array}$ & $\begin{array}{c}1.06 \pm \\
0.23\end{array}$ & $\begin{array}{c}1.14 \pm \\
0.23\end{array}$ & $\begin{array}{c}0.34 \pm \\
0.12\end{array}$ \\
\hline 0.250 & $\begin{array}{l}0.048 \pm \\
0.020\end{array}$ & $\begin{array}{c}0.29 \pm \\
0.07\end{array}$ & $\begin{array}{c}0.52 \pm \\
0.20\end{array}$ & $\begin{array}{c}3.95 \pm \\
0.67\end{array}$ & $\begin{array}{l}7.02 \pm \\
1.81\end{array}$ & $\begin{array}{c}0.34 \pm \\
0.10\end{array}$ & $\begin{array}{c}1.31 \pm \\
0.33\end{array}$ & $\begin{array}{c}0.51 \pm \\
0.18\end{array}$ & $\begin{array}{c}0.11 \pm \\
0.04\end{array}$ \\
\hline 1 & $\begin{array}{l}0.02 \pm \\
0.008\end{array}$ & $\begin{array}{c}0.07 \pm \\
0.02\end{array}$ & $\begin{array}{c}0.12 \pm \\
0.04\end{array}$ & $\begin{array}{c}2.23 \pm \\
0.39\end{array}$ & $\begin{array}{l}5.16 \pm \\
1.01\end{array}$ & $\begin{array}{c}0.07 \pm \\
0.02\end{array}$ & $\begin{array}{c}0.38 \pm \\
0.10\end{array}$ & $\begin{array}{c}0.24 \pm \\
0.04\end{array}$ & $\begin{array}{c}0.05 \pm \\
0.01\end{array}$ \\
\hline 2 & $\begin{array}{l}0.017 \pm \\
0.005\end{array}$ & $\begin{array}{c}0.12 \pm \\
0.03\end{array}$ & $\begin{array}{c}0.19 \pm \\
0.02\end{array}$ & $\begin{array}{c}7.60 \pm \\
1.92\end{array}$ & $\begin{array}{l}7.00 \pm \\
0.36\end{array}$ & $\begin{array}{c}0.23 \pm \\
0.02\end{array}$ & $\begin{array}{c}0.34 \pm \\
0.06\end{array}$ & $\begin{array}{c}0.48 \pm \\
0.01\end{array}$ & $\begin{array}{c}0.04 \pm \\
0.01\end{array}$ \\
\hline 3 & $\begin{array}{l}0.016 \pm \\
0.005\end{array}$ & $\begin{array}{c}0.05 \pm \\
0.03\end{array}$ & $\begin{array}{c}0.24 \pm \\
0.10\end{array}$ & $\begin{array}{c}3.75 \pm \\
1.30\end{array}$ & $\begin{array}{l}5.03 \pm \\
1.84\end{array}$ & $\begin{array}{c}0.16 \pm \\
0.07\end{array}$ & $\begin{array}{c}0.23 \pm \\
0.02\end{array}$ & $\begin{array}{c}0.22 \pm \\
0.05\end{array}$ & $\begin{array}{c}0.04 \pm \\
0.01\end{array}$ \\
\hline 4 & $\begin{array}{l}0.011 \pm \\
0.001\end{array}$ & $\begin{array}{c}0.03 \pm \\
0.01\end{array}$ & $\begin{array}{c}0.08 \pm \\
0.01\end{array}$ & $\begin{array}{c}3.73 \pm \\
0.85\end{array}$ & $\begin{array}{l}4.83 \pm \\
0.50\end{array}$ & $\begin{array}{c}0.11 \pm \\
0.03\end{array}$ & $\begin{array}{c}0.27 \pm \\
0.07\end{array}$ & $\begin{array}{c}0.18 \pm \\
0.04\end{array}$ & $\begin{array}{c}0.05 \pm \\
0.01\end{array}$ \\
\hline 8 & $\begin{array}{l}0.014 \pm \\
0.003\end{array}$ & $\begin{array}{c}0.05 \pm \\
0.02\end{array}$ & $\begin{array}{c}0.11 \pm \\
0.05\end{array}$ & $\begin{array}{c}3.17 \pm \\
0.26\end{array}$ & $\begin{array}{l}4.67 \pm \\
0.29\end{array}$ & $\begin{array}{c}0.10 \pm \\
0.02\end{array}$ & $\begin{array}{c}0.23 \pm \\
0.03\end{array}$ & $\begin{array}{c}0.12 \pm \\
0.01\end{array}$ & $\begin{array}{c}0.01 \pm \\
0.01\end{array}$ \\
\hline 12 & $\begin{array}{l}0.013 \pm \\
0.004\end{array}$ & $\begin{array}{c}0.02 \pm \\
0.01\end{array}$ & $\begin{array}{c}0.03 \pm \\
0.02\end{array}$ & $\begin{array}{c}2.61 \pm \\
1.20\end{array}$ & $\begin{array}{l}4.30 \pm \\
0.01\end{array}$ & $\begin{array}{c}0.07 \pm \\
0.02\end{array}$ & $\begin{array}{c}0.22 \pm \\
0.04\end{array}$ & $\begin{array}{c}0.11 \pm \\
0.03\end{array}$ & $\begin{array}{c}0.02 \pm \\
0.01\end{array}$ \\
\hline 24 & $\begin{array}{c}0.012 \pm \\
0.004\end{array}$ & $\begin{array}{c}0.02 \pm \\
0.00\end{array}$ & $\begin{array}{c}0.03 \pm \\
0.01\end{array}$ & $\begin{array}{c}1.07 \pm \\
0.15\end{array}$ & $\begin{array}{l}2.31 \pm \\
0.14\end{array}$ & $\begin{array}{c}0.08 \pm \\
0.03\end{array}$ & $\begin{array}{c}0.21 \pm \\
0.04\end{array}$ & $\begin{array}{c}0.12 \pm \\
0.03\end{array}$ & $\begin{array}{c}0.02 \pm \\
0.01\end{array}$ \\
\hline
\end{tabular}

\section{DISCUSSION}

A molecule biodistribution in an organism depends on a series of physical, chemical, and physiological factors (pharmacokinetic process), such as administration route; dosage form; drug liberation rate, diffusion, penetration, permeation, and distribution within the body fluids and tissues; biotransformation type, amount, and rate; recycling processes; and elimination. Distribution rate for each organ tissue is determined by the blood perfusion and the facility of passing through vessels and penetrating the cell (6). Diffusion time for different tissues, identification of target tissue, and residence time are important information revealed by biodistribution studies. 
Radioisotopes were chosen as radiotracers based on the molecule chemical structure, convenience of the labelling method, and labelled detection in different biological samples.

Technetium-99m radioisotope label was chosen for this pharmacokinetic study with bee venom due to its favourable radiation characteristics, possibility of labelling all bee venom components, easy availability, and low costs.

lodine-125 has been indicated for innumerous applications due to its easy, simple and safe radioiodination system, labelled product stability, and detection facility (2). However, radioiodination shows some limitations for labelling reaction with mixtures and small molecules. lodine-125 binding in molecules occurs in the tyrosine amino acid (and in some special conditions, in the histidine or tryptophan). These amino acids are present in the primary structure of PnTX2-6, but they did not appear in all the bee venom components.

In some cases, this radioisotope size causes some important structure alterations or active site blockade with loss of biological activity. So, it must be checked if the radiotracer maintains the native toxin properties in control tests.

The obtained radiotracers yield and radiochemical purity analyses were all adequate, giving warranty for biodistribution assays.

The first study was done with purified PnTX2-6 toxin obtained from Phoneutria nigriventer venom. This spider is responsible for a great number of arachnid accidents in Brazil (3), which can be very severe in aged men and children. Its venom caused intense pain, salivation, dyspnea, vomit, and priapism when subletal doses were administered in male dogs. Various toxins were identified in this venom (7), and PnTX2-6 has been completely sequenced. It has 5,290 Daltons and specific activity at sodium channels (8).

${ }^{125}$ I-PnTX2-6 biodistribution analysis suggested that the major percentage of the labelled toxin uptake occurred in the kidneys, and indicated that it is practically eliminated by the renal excretion. Organs with larger vascularization, in an increasing order, are the lung, spleen, heart, and liver. The lung is a critical organ because respiratory distress and possible pulmonary oedema are serious symptoms observed in patients. The heart may be a target organ for this toxin since cardiac alterations were observed in experimental assays and patients (5).

In heart muscle cells, high intracellular sodium concentration promotes calcium release from the sarcoplasmatic reticulum. An abrupt rise in the cytosolic calcium can 
trigger rapid concentration mechanism and produce characteristic ultrastructural damage in the cardiac and skeletal muscle fibbers of amphibians and mammals (9). Presence of toxin in the liver suggests hepatic metabolism. A rapid brain uptake within 0.083 hours after the injection indicated that the tracer had an efficient passage through the intact blood-brain barrier. One part (non-specific binding and free ligands) of the radioactivity was washed out from the brain about 1 hour after the injection, while the remainder fraction (specific binding) was retained for a long time (about $20-25 \%$ of the brain accumulated radioactivity). This binding proved to be efficient in the brain, and remained metabolically stable at the binding sites for a sufficient long period. It also remained stable for a longer period in the testicles and muscles, but at low concentrations.

In the muscle, this fact is probably related to myonecrosis by a direct action on the sarcolemma, which first changes its permeability to sodium ions and promotes osmotic-like alterations (muscle cell vacuolation); and by a secondary indirect action, in which membrane disruption occurs as a response to the intracellular pressure and cell volume uncontrolled increase due to sodium and calcium ions influxes (9).

The second sample analysed was Apis mellifera venom. It is a complex mixture of biogenic amines, peptides, and enzymes. All its components have synergetic action leading to local, humoral, and systemic effects (1). Men have been victims of attacks by bees, which use venom to protect their colonies from intruders. Depending on the victim immunological sensitivity and number of stings, anaphylaxis or other pathological effects can occur. Therefore, it is interesting to know more details about the venom activity duration, distribution, and retention in animal models, particularly regarding to the biological effects observed in its victims.

Analysis of the data obtained from Apis mellifera venom demonstrated that the kidneys and liver showed higher radiotracer concentration in all periods of time, while spleen, heart, and brain presented the lowest quantities. The quantities found in the liver suggest that a hepatic metabolism may have happened. The quantity detected in the skeletal muscle confirms this tissue selectivity for bee venom, and that induced mionecrosis can be related to $\mathrm{PLA}_{2}$ and melitin action (1). The venom radioactivity profile detected in the kidneys over 24 hours suggests that they may excrete the toxin or some of its metabolites. It was expected that the kidneys would be the main elimination route, but the amount excreted by feces showed to be more important. 
This fact may be caused by the venom nefrotoxicity. Therefore, any venom compound could have hepatic and renal metabolism.

Reabsorption was observed in both assays: with ${ }^{125} \mathrm{I}$-PnTX2-6 toxin and with ${ }^{99 \mathrm{~m}} \mathrm{Tc}$ bee venom. Radioactivity concentration increase in diverse organs occurred just after the increase in the blood stream and decrease in the stomach and intestine, which suggests that these organs could be included in transcellular reservoirs. According to Mattiello-Sverzuta et. al. (9), there is a mechanism of slow gastric release caused by spider venom intravenous injection, so the stomach may be a target organ for the PnTX2-6 toxin. There is no similar data for bee venom.

After clearance of the non-specific and free ligands from the whole organs analysed, the internalised radioactive molecule demonstrated to have similar slope in fitting curves with very long residence time for both, ${ }^{125} \mathrm{I}-\mathrm{PnTX} 2-6$ toxin and ${ }^{99 \mathrm{~m}} \mathrm{Tc}$-bee venom.

\section{CONCLUSION}

Biodistribution study conducted with radiotracers can be successfully used in animal venom and toxin studies. This method is sensitive, accurate, and simple to be applied.

It allowed in vivo observations of the Apis mellifera venom and PnTX2-6 toxin (isolated from Phoneutria nigriventer venom) behaviour.

\section{ACKNOWLEDGMENTS}

We are grateful to MSc Miriam Fussae Suzuki for the careful English revision and PhD Maria Tereza CP Ribela for helping with radioiodination. This work was supported by CNPq, CAPES. 


\section{REFERENCES}

1 BARRAVIERA B. Acidentes por abelhas e vespas. In: BARRAVIERA B. Ed. Venenos animais: uma visão integrada. Rio de Janeiro: EPUC, 1994: 339-44.

2 BEHR Th.M., GOTTHARDT M., BECKER W., BÉHÉ M. Radioiodination of monoclonal antibodies, proteins and peptides for diagnosis and therapy. Nuklearmedizin, 2002, 41, 71-9.

3 BUCARETCHI F., DEUS REINALDO CR., HYSLOP S., MADUREIRA PR., DE CAPITANI EM., VIEIRA RJ. A clinical-epidemiological study of bites by spiders of the genus Phoneutria. Rev. Inst. Med. Trop. São Paulo, 2000, 42, 17-21.

4 CAMILLO MAP., PAES PCA., TRONCONE LRP., ROGERO JR. Gyroxin fails to modify in vitro release of labelled dopamine and acetylcholine from rat and mouse striatal tissue. Toxicon, 2001, 39, 843-53.

5 COSTA SKP., HYSLOP S., NATHAN LP., ZANESCO A., BRAIN SD., NUCCI G., ANTUNES E. Activation by Phoneutria nigriventer spider venom of autonomic nerve fiber in the isolated rat heart. Eur. J. Pharmacol., 1998, 363, 139-46.

6 GIBALDI M. Compartmental and noncompartmental pharmacokinetics. In: GIBALDI M. Ed. Biopharmaceutical and clinical pharmacokinetics. Philadelphia: PA. Lea \& Febiger, 1991: 1-16.

7 KALAPOTHAKIS E., PENAFORTE CL., BEIRÃO PSL., ROMANO-SILVA MA., CRUZ JA., PRADO MAM., GUIMARÃES PEM., GOMEZ MV., PRADO VF. Cloning of cDNAS encoding neurotoxic peptides from the spider Phoneutria nigriventer. Toxicon, 1998, 36, 1843-59.

8 MATAVEL A., CRUZ JS., PENAFORTE CL., ARAÚJO DAM., KALAPOTHAKIS E., PRADO VF., DINIZ CR., CORDEIRO MN., BEIRÃO PSL. Electrophysiological characterization and molecular identification of the Phoneutria nigriventer peptide toxin PnTx2-6. FEBS Letters, 2002, 523, 219-23.

9 MATTIELLO-SVERZUTA AC, CRUZ-HÕFLING MA. Toxin 2 (PhTx2), a neurotoxic fraction from Phoneutria nigriventer spider venom, causes acute morphological changes in mouse skeletal muscle. Toxicon, 2000, 38, 793-812. 